\title{
EFL STUDENT'S PROBLEMS WITH PARAGRAPH WRITING AT TAY DO UNIVERSITY, VIETNAM
}

\author{
Thi Tra My Ly, \\ Thi Thuy Hang Nguyen, \\ Thi Minh Uyen Phan', \\ Thi Thuy Ha Dinh, \\ Thuy Vi Huynh \\ Tay Do University, \\ Vietnam
}

\begin{abstract}
:
This paper studied problems in EFL students' paragraph writing. The research participants were first-year students of English in Tay Do University (TDU). To achieve the desired aims of the current study, the researcher combined both qualitative and quantitative methods, using questionnaires, interviews, and observations as the main instruments. The researcher used the package of social sciences (SPSS) for analysis. Research results showed that the freshmen at TDU often encountered problems in writing paragraphs. These accounted for grammatical structures, vocabulary, and coherence. Basing on the research results, students could recognize their difficulties when writing and find some new ways to overcome them. It is suggested that teachers should find and update some new teaching methods so as to develop students' paragraph writing skills.
\end{abstract}

Keywords: semantic prosody, prosodic awareness, collocations, near synonyms, EFL learners

\section{Introduction}

Chapter I shows the rationale, research aims and research questions, the significance, and organization of the study.

\subsection{Rationale}

Nowadays, English is considered the common language of the world. According to Vietnamnet (an electronic newspaper in Vietnam under the Ministry of Information and Communications of Vietnam), "English is used by over 527 million people worldwide as a

\footnotetext{
${ }^{i}$ Correspondence: email ptmuyen@tdu.edu.vn
} 
mother tongue, and it is spoken in 101 countries in 2019". Obviously, learning English in Vietnam is also considered very significant in the process of developing the country. Brown (2000) states that languages consist of four main skills such as reading, listening, writing, and speaking. Hence, learners should be exposed to all the mentioned skills to master the English language successfully. Among four essential skills, writing plays a very important role in learning, and paragraph writing is considered as the first main part in the syllabus of students in a university. This study is to investigate the problems encountered by students with their paragraph writing skills.

It is a fact that writing has been considered a difficult boring subject by language learners. It takes much time to advance this skill. Students in general and first-year EFL students in particular are very weak at paragraph writing. There are many hypotheses about the reasons why English major students face a number of problems when studying writing paragraphs. Firstly, it is assumed that students are not familiar with writing paragraphs because they just learned writing at the lower level such as sentence rewriting and sentence building which focus much on grammatical aspects. Secondly, to improve paragraph writing skills, students need not only to achieve a certain language proficiency level but also to practice writing regularly. However, pupils have few opportunities and time to practice in class, so they do not have much experience in writing skills. Thirdly, vocabulary is a big difficulty for them. They do not have enough vocabulary to express their thoughts or opinions. They feel confused and make many mistakes in vocabulary when they are writing a paragraph. It makes them afraid of writing. Moreover, grammatical structures strongly affect their writing. They cannot write correctly since there are too many grammatical structures for them to remember. Next is the influence of mother tongue. Students may tend to write what is thought in the native language style but not in the English structures because the mother tongue they have is not English. Lastly, students do not know how to organize their ideas in a paragraph. They do not make an outline before writing. As a result, it is hard to have perfect writing when students usually make mistakes in their writing process.

Nevertheless, writing paragraphs helps to foster the learners' creativeness and imagination in language use. In a better position, writing serves as tangible learning evidence for the learners. Therefore, the learners' writing paragraph skills may help to hone their learning abilities and to develop creative thinking and developed ideas in other language skills. Most importantly, writing is both an essential part of the learning process and one of the most important ways that help the learners to communicate their ideas to others. In some countries (e.g., the United States and Canada), writing has become a major part of formal education. It also helps to develop visual thinking and idea development. At Tay Do University, paragraph writing is conducted for the freshmen due to the fact that it is one of the basic and fundamental skills. Paragraph writing is the background for students to learn other writing skills in the next term. For example, they will learn to write letters, emails in terms of business, etc.

The above reasons encouraged the researcher to carry out the survey entitled "EFL student's problems with paragraph writing at Tay Do university". 


\subsection{Research aims and research questions}

\subsubsection{Research aims}

English has not only been considered as an international language but is also used widely in the world. It is becoming a more and more important subject in schools and universities. However, it is not easy to learn English. Students often make mistakes in using it, especially in writing skills. Therefore, the study was conducted to investigate mistakes in writing paragraphs of English-majored freshmen at Tay Do University.

\subsubsection{Research questions}

The study attempts to answer the following questions:

1. What types of common mistakes do EFL students at Tay Do University encounter writing paragraphs?

\subsubsection{Significance of the study}

It is significant to carry out this study because it investigates the common issues that EFL students at Tay Do University face in writing paragraphs. In addition, it would provide clues for the educators about the types of errors the first-year students commit when they are writing a paragraph. Therefore, the freshmen at university have a chance to know what mistakes they have faced.

\subsubsection{The organization of study}

The study includes five chapters:

Chapter 1: Introduction

Chapter 2: Literature review

Chapter 3: Research methodology

Chapter 4: Results and Discussion

Chapter 5: Conclusion, limitations, and recommendations

\section{Literature review}

This chapter presents the definitions of writing and the reasons of learning writing; the definitions and classifications of paragraphs; common problems of writing paragraphs; and previous studies.

\subsection{Definitions of writing}

Writing is one of the language skills which are important to our life. Conveying information, making transactions, and expressing one's emotions are made easily through writing. There are diverse conceptions of writing given by many different researchers.

Accordingly, writing is defined as the activity of forming many graphic symbols only in a letter or combinations of letters (Byrne, 1988). The expression is simply revealed by emblems. The system of signs and tokens can show exactly what we want to say to the reader in paper. Sokolic (2003) also states that writing is a physical and mental act. It 
means that writers should pass writing to convey the words, thoughts, and ideas in the head and to organize them into sentences and paragraphs. It is about discovering how to communicate notions and develop them in statements and paragraphs that will be comprehensible to a reader.

From a different point of view, according to Marilou Orang (2011), writing is a way of knowing and discovering what you know as what you put it down. Capitalize is not only in the form of words and phrases but of drawing ideas and images and all other wonderful stuff in your mind that only become clear as writers engage in the process of writing it down. You may not know what you are going to write until you write it. Also, according to Klein (1985), writing is the ability to put down a pen and paper to express ideas through symbols. This way of representation on the paper will have meaning and content that could communicate to other people by the writer.

To summarize, writing skill is an expression of the mental and physical activity in order to help writers use his or her own language to express, analyze, prove, or convince about a specific topic in a structured form.

\subsection{The importance of writing}

Writing plays an important role in learning English. According to Rao (2007), EFL writing is useful in two ways: first, it motivates student's thinking, organizing ideas, and developing their ability to summarize, analyze, and criticize. Second, it strengthens students' learning, thinking, and reflecting on the English language. Bello (1997) also indicates that writing also enhances language acquisition as learners experiment with words, sentences, and larger chunks of writing to communicate their ideas effectively and to reinforce the grammar and vocabulary they are learning in class.

When students write, they have a chance to understand deeply the language. Writing also reinforces the knowledge that students have learned such as vocabulary, word usage, grammatical structures, etc. Moreover, writing also offers students the opportunities to adventure and embrace the new language. In addition, writing also motivates students' thinking, creativity, and comment ability. Consequently, good writing skills will help students explore and learn other skills in a comprehensive and effective way.

\subsection{Definition of paragraphs}

The term paragraph has many definitions in the relevant literature. The following are a few among many. According to J.M Red (1988), a paragraph is a series of sentences that develops one idea. It is a set of related sentences dealing with a single topic. Together, the sentences of the paragraph explain the writer's main idea (the most important idea) about the topic. In academic writing, a paragraph is often between five and ten sentences long. Besides, "a paragraph is a short paper of around 150-200 words. It usually consists of an opening point called a topic sentence followed by a series of sentences which support that point" (Langan, 2001).

Also, according to Oshima and Hogue (2006), an English paragraph structure requires three important elements including the topic sentence, the supporting sentences, 
and the closing sentence. The topic sentence is the most general statement. It explains the topic with general ideas. It introduces the paragraph and tells the reader what your paragraph is going to be about. The topic sentence is a helpful guide to both the writer and the reader. It tells the writer what information to include and it tells the reader what the paragraph is going to be about and is thus better prepare to understand it. The usual position of the topic sentence is at the beginning of the paragraph, but it can sometimes occur anywhere in such unit. Supporting sentences (main points) come after the topic sentence and support the topic sentence. These are sentences that talk about, explain, or prove the topic sentence by giving more information about it. The supporting sentences with their supporting details make up the body of a paragraph. The concluding sentence (conclusion) is considered as an end of a paragraph. It restates the main idea of the paragraph by using different words and tells the reader what you are writing about. Moreover, it leaves the reader with important points to remember for instance.

On the other hand, paragraphs should contain the following that a writing paragraph should have. First of all, an effective paragraph has unity. A paragraph is unified when it states only one central idea that is developed by all other statements in the paragraph. The entire paragraph should concern itself with a single idea. The sentences combine to produce a single, complete unit of those. Second, cohesion in a paragraph is certainly an important thing. It makes the paragraph meaningful and easy to follow. The illustration sentences are organized in a clear way.

To sum up, a paragraph is built around a central idea. Each paragraph should have a topic sentence. The topic sentence presents the main idea of that one. It is also called a controlling idea since it limits the subject of the paragraph. In unified paragraphs, all sentences are related to the topic sentence by explaining with facts, examples, and supporting ideas. Paragraph writing is the first step toward other forms of writing.

\subsection{Classification of paragraphs}

A paragraph is the fundamental writing type which is chosen to teach for EFL students at any university. According to Cheryl Pavlik (2006), paragraphs are divided into three types including descriptive, contrast, and argumentative ones. A descriptive paragraph is one that describes a picture, a person, a place, an activity, or another thing. Oshima \& Hogue (2006) also state that descriptive genre is a kind of text that tells to the readers how something looks, feels, smells, tastes, and sounds as if the readers can imagine what the writer means in their mind. It makes sure that a reader can clearly know and imagine what a writer writes in a paragraph.

On the other hand, a contrast paragraph is to compare how two people, places, sports, or things are similar. In addition, a comparison one is also to discuss how two people, places, sports, or things are different. From this type, we can recognize the advantages and disadvantages of the topic. The last one in the three types is an argumentative paragraph. The main purpose of argumentative paragraphs is to persuade the readers to agree with his or her opinion about a controversial topic. Argumentative paragraphs discuss the writer's opinions. The writer writes protecting or contrasting opinions about the issue. Argumentative paragraphs can improve our knowledge from 
the opinions of everyone. The writer should be able to guide the reader to be sure of the writers' opinions so that the writer has to write their arguments clearly.

\subsection{Common problems of writing paragraphs}

English is widely used and popular all over the world, and writing paragraphs is also emphasized. Many researchers have studied various important aspects of paragraph writing. After screening, this study will point out some common mistakes when students write paragraphs:

\section{a. Problems with vocabulary}

In language learning, vocabulary plays an extremely important position and is compared to bricks that are indispensable in building houses. M.A Hajar (2015) shares in a study that the lack of vocabulary is one of the sources that make a paragraph less attractive. As the result, students will be unable to express their ideas freely and accurately because of their limited lexicons. Furthermore, students also meet difficulties in the way of using words. Some words may have various meanings, or some different words can have the same meanings. Therefore, students often make mistakes when writing such as using a wrong word or confusing this word with another. Ali Aljaily (2016) notes that "Good writers are concise and precise, weeding out unnecessary words and choosing the exact word to convey meaning".

Specifically, there is a so-called polysemy in English which means one single word can denote different meanings in different situations. According to Gowere (1995) "Due to the influence of other languages, variant pronunciations, and other historical reasons, the English spelling system which has become inconsistent is complex for students". Therefore, the phenomenon of confusion between words often occurs when students mistake a word for another because they look similar to the word they want to use.

Besides, M. A. Hajar (2015) notes that "the interference of mother tongue deeply affects to the paragraphs and teachers should choose an effective methodology for teaching writing, familiarize students with useful ways of learning English". Aside from this, it is also assumed that students usually think in their native language before writing what they think in English. Accordingly, they usually translate each word into English. Thereby, it is undeniable that some paragraphs may contain lexical errors and hence confuse readers.

\section{b. Problems with grammar}

Numerous studies have been conducted about the problems in terms of grammar that students encounter when writing paragraphs. Some focused on grammatical range, and others paid attention to grammatical accuracy. It was found that grammar was extremely important in conveying accurate messages, and there are some key grammatical forms as tenses, voices, modals, articles, nominalizations, and logical connectors (Dudley Evans \& St John, 1998). Moreover, grammar is the most difficult area for writers. Ammar Hussen (2017) reveals that the learners suffer from many types of difficulties such as grammatical and structural difficulties as well as difficulties in using punctuation marks and definite and indefinite articles. 
According to Tyner (1987) "As verbs take different forms depending on tense and subjects they are used with, they create problems for second language writing students", so learners have a number of problems in their attempts to write in the second language. Also, there are many grammatical structures in English, and this causes difficulty for learners to use them correctly. Furthermore, English structures are different from Vietnamese ones. Structures give difficulty to students when using them proficiently. The mismatch between the two languages creates a big barrier for learners who make their first attempts to write in the target language.

\section{c. Problems with paragraph coherence}

According to Rebecca Stott and Peter (2001), coherence is the first essential in a text, recognizable structure of thought and ideas. A paragraph can be as short as one sentence or as long as ten sentences. However, the number of sentences is not as important as the coherence. It is the factor that makes the paragraph understandable to readers. It is a logical connection among the ideas and must reasonably be ordered. The information which is well organized is easier to remember and understand. However, so many learners do not know how to organize the ideas in a paragraph so as to make the paragraph more attractive. Ali Aljaily (2016) shows that the students are not aware enough of English paragraph organization. Thereby, some paragraphs are not attractive and confuse readers.

According to Husna (2013), "Good organization will help the readers better to understand the ideas presented". In fact, students have difficulty in writing that writers do not know how to express their ideas clearly and convincingly. They do not know what idea should be written first and which one is next. Fundamental features of good writing include the study of cohesion and coherence, macro structure of text, logical arrangement of information, and story structure (Grab \& Kaplan, 1996). Coherence is helped by cohesion which is the process of cohering one sentence to the next sentence (Bex, 1996). Cohesion is an idea that is mostly used to look at sub units within a text. It refers to the way a speaker or a writer uses the built-in relationship between words, phrases, and sentences to create a sense of connection (Ammar, 2017).

To summarize, lack of vocabulary, a poor grasp of grammatical structures, and problems with paragraph coherence are some of the writing difficulties faced by the students. These difficulties not only affect learners' academic success but also hinder their professional progress.

\section{d. Previous studies}

This part of chapter II discusses the previous studies that are found related to paragraph writing difficulties faced by EFL students.

The first research that should be mentioned is "The first year language students difficulties in paragraph writing and some appropriate strategies to solve these problems at the national economic university (NEW)" by Bui (2007). This study was conducted to survey students' common errors in writing paragraphs, to solve students' these problems by appropriate strategies, and to provide teachers of English at NEW the real situation about 
students' difficulties. The students' writing tasks were used for quantitative data collection. The questionnaire was used for qualitative data collection. The result showed that students made errors in idea organization and content when writing a paragraph. Moreover, the result also gave the best teaching methodologies to develop writing paragraph skills by using various activities in teaching.

In 2015, Hajar carried out the research "A Study of Errors in the Paragraph Writing of EFL Learners: A Case Study of First Year Translation Students at University of Applied Science and Technology in Bushehr, Iran" to survey the errors students made in paragraph writing. The subjects were 70 first-year Translation students at Bushehr University of Applied Science and Technology. The instrument used in this research was a general English proficiency test for determining the proficiency level in English of the participants for quantitative data and a questionnaire for qualitative data. The result of study revealed that the total number of errors in paragraph writing were 165 . Through observation, it is seen that the largest numbers of errors were in supporting sentences. The number of errors in supporting sentences is more than in topic and concluding sentences. In addition, the lack of knowledge in grammar, vocabulary, interference of mother tongue, and lack of sufficient practice in writing are the other sources of errors in paragraph writing in this research. Teaching method is also mentioned in this research, and it is an important aspect affecting to students.

The research "Analysis of Errors in Paragraph Writing in English by Second Year Geography \& History Students at University of Baghdad" by Sawsan 2011 is also found relevant to the current study. This study was to study, classify, describe, and explain the causes for the most common errors found in the English writing paragraph of the secondyear geography \& history students at university of Baghdad. In this study, the errors have been classified as grammatical difficulties (misuse of tense, misuse of singular/plural form, subject-verb agreement, article, prepositions, word order), and mechanical difficulties (punctuation, spelling, lexical difficulties). The author of this study collected 60 paragraphs of the second-year students of the College of History and Geography at Baghdad University. The students of History Department are asked to write a paragraph in English about the history of Roman. On the other hand, the students of Geography are asked to write a paragraph in English about subjects that are selected from their textbook. The result of this study showed that both History and Geography made errors in grammar and spelling more often than the other errors that are also surveyed. It has been found out that the students have got a poor mastering of a number of aspects in writing a paragraph in English.

In conclusion, these studies above have found out some common problems and difficulties students faced in their writing paragraphs. They were problems with vocabulary, grammar, content, interference of mother tongue, etc. The researchers utilized various methods in studies such as a questionnaire, an interview and tests. These researches provide fundament and premises for the current study. 


\section{Methodology}

This chapter presents the research design, participants, instruments, data analysis and research procedures.

\subsection{Research design}

The research was carried out to find out the problems that the freshmen faced in writing paragraphs. The reliability and validity of the research results were based on the instruments as questionnaire and interview questions, and observation. The research participants were all the English-majored freshmen who would be delivered the questionnaire to get the necessary information about their difficulties in writing. Also, 30 students from these freshmen were randomly selected in order to do a writing paragraph test. Moreover, ten students were randomly invited to participate in a paper interview. As a result, this survey was a combination of quantitative and qualitative research.

\subsection{Research participants}

All the first-year students of English major at Tay Do University were invited to participate in this research on a voluntary basis. Their ages ranged from 18 to 21 . Most of them had been learning English for 8 years and a few had 10 and 12 years of learning. They spoke Vietnamese as their mother tongue and English was considered as their foreign language. The reasons for choosing these participants were based on the subject they were learning and their psychological age. These participants were nearly at the same age and almost shared the same years of learning English. This was to ensure that participants had similar ways of thinking and faced some similar difficulties. Therefore, it would be easier during the process of collecting data.

\subsection{Instruments}

The instruments of this research were a questionnaire, an interview and observation. Questionnaire was used to find out problems of freshmen in English paragraph writing because it provided an easy practical way for collecting data from quantities of people in a short time. Besides, the interview was another helpful tool used for getting more specific details. Along with two methods mentioned, observation was another helpful tool used to gain more insights into students' thinking and their problems.

\subsubsection{Questionnaire}

The questionnaire for students embraced two parts. Part 1 consisted of seven questions aiming to investigate students' background. In the second part of the questionnaires, there were 21 statements listed in tables. Questions $1-15$ focused on students' problems in terms of vocabulary and grammar. Questions $16-21$ related to coherence. The remaining statements presented additional problems that also affected students' writing a paragraph.

To explore the participants' awareness on the difficulties in writing a paragraph, five-point scales were used namely strongly agree, agree, no idea, disagree and strongly 
disagree. The five-point scales were employed to figure out the extent to which students evaluated their writing skill. The scales were named as very good, good, average, bad and very bad. To evaluate the importance of writing, five point scales were utilized namely very important, important, normal, not important and not important at all. Similarly, five-point scales were utilized to get the information about students' evaluation of writing paragraphs in English. Namely very difficult, difficult, normal, easy and very easy,

\subsubsection{Interview}

The purpose of using interview questions was to understand students' problems when writing a paragraph. The paper interview was a very useful tool when collecting information from students because when answering questions, they clearly expressed their own ideas. The research chose ten students randomly (six girls and four boys) in a total of freshmen to answer interview questions. The paper interview consisted of four questions getting insights into the attitude of students when learning writing, and the problems students encountered in writing paragraphs.

\subsubsection{Observation}

Observation was clearly a tool and a piece of evidence to demonstrate the difficulties of students when writing. Therefore, 30 students were invited to take part in a paragraph writing test allotted in about 30 minutes. They were asked to write a paragraph with the topic "Describe a holiday that you know" The tests then were collected and marked by a writing teacher in the same school. The writing test results were analyzed in terms of the problems that student participants made in their writing.

\subsection{Data analysis}

After the researcher collected the required data through questionnaires, interview and paragraph writing tests, she used the following procedures for the data analysis.

As for the questionnaire data analysis, to make the data analysis of the questionnaire less complicated, the researcher used SPSS. In that case, the five-points scale was transferred into five values as demonstrated: Strongly agree $=5 ;$ Agree $=4 ;$ No idea $=3$; Disagree $=2$; Strongly disagree $=1$.

Similarly, the five-point scale was transferred into five values to access students' thinking about learning writing namely: Very important $=5 ;$ Important $=4 ;$ Normal $=3 ;$ Not important $=2$; Not important at all $=1$.

As for participants' evaluation about their writing skill, the five-point scale was also transferred into five values such as Very good =5; Good = 4; Average = 3; Bad = 2; Very $b a d=1$.

And the five-point scale was transferred into five values to evaluate writing paragraphs in English as Very difficult = 5; Difficult = 4; Normal =3; Easy = 2; Very easy = 1 . Organizing the quantitative data in a table in accordance with the frequency of occurrence of the answer, the researcher also applied descriptive statistics and One-sample t-test. In addition, to ensure the accuracy of the results, the researcher used Reliability Statistic after each cluster. 
For the observation analysis, after the tests were marked by a writing English teacher, the written paragraphs were gathered and read again and again line by line to identify the problems of sample students in writing the paragraphs. The researcher tried to categorize according to their frequency of occurrence in students' paragraphs. After that, the categorized numeric data was interpreted by using Excel Software.

Finally, the researcher also used an interview to develop the analysis of the data. The responses were collected and deeply analyzed according to their main problems in paragraph writing.

\subsection{Procedures}

The research lasted about 12 weeks and it was divided into 3 steps. All the activities of conducting the study were listed in the following table:

\begin{tabular}{|c|c|}
\hline Duration (12 weeks) & $\begin{array}{l}\text { Activities in study process } \\
\end{array}$ \\
\hline $\begin{array}{l}\text { Step 1: from the } \\
1^{\text {st }} \text { week to } 5^{\text {th }} \text { week }\end{array}$ & $\begin{array}{ll}\text { - } & \text { Correcting the research topic and submitting the research proposal } \\
\text { - } & \text { Researching materials to support the research } \\
\text { - } & \text { Designing the framework of the research } \\
\text { - } & \text { Designing questionnaires }\end{array}$ \\
\hline $\begin{array}{l}\text { Step 2: from the } \\
6^{\text {th }} \text { week to } 9^{\text {th }} \text { week }\end{array}$ & $\begin{array}{ll}\text { - } & \text { Asking the teacher for the permission of delivering questionnaires } \\
\text { - } & \text { Delivering the questionnaires to students } \\
\text { - } & \text { Collecting the data from the questionnaires }\end{array}$ \\
\hline $\begin{array}{l}\text { Step 3: from the } \\
9^{\text {th }} \text { week to } 12^{\text {th }} \text { week }\end{array}$ & $\begin{array}{ll}\text { - } & \text { Analyzing the collected data from questionnaires and observation. } \\
\text { - } & \text { Completing the paper }\end{array}$ \\
\hline
\end{tabular}

\section{Results and Discussion}

This chapter presents the results of the research based on the reliable data collected from a questionnaire, an interview and observation. The results indicate the problems in learning writing paragraphs of the freshmen through statistical evidence.

\subsection{Results}

After collecting all the necessary information and ideas from 102 participants who were freshmen at Tay Do University in the questionnaire and 30 people in the observation and 10 students in the interview, the data were analyzed. The findings were divided into three groups including the results of the questionnaire, the interview, and the results of observation.

\subsection{Results from data of the questionnaire}

4.2.1 Students' opinion in learning English and their estimation in writing paragraphs The results from this table reveals that students highly estimated the importance of learning English (mean=4.25, $\mathrm{SD}=.776, \mathrm{t}=3.189$, $\mathrm{df}=101, \mathrm{p}=.002$ ). However, they thought that writing paragraphs was really difficult with the evidence (mean=3.34, $\mathrm{SD}=.711$, $\mathrm{t}=4.877, \mathrm{df}=101, \mathrm{p}=.000)$. 
Table 1: Students' opinion in learning English and their estimation in writing paragraphs

\begin{tabular}{|l|c|c|c|c|c|c|c|c|c|c|}
\hline \multirow{2}{*}{ Ideas } & \multicolumn{3}{|c|}{ Descriptive statistics } & \multicolumn{6}{|c|}{ One-Sample test (test value =4) } \\
\cline { 2 - 10 } & Min. & Max. & Mean & $\begin{array}{c}\text { Std. } \\
\text { Deviation }\end{array}$ & $\mathbf{t}$ & $\mathbf{d f}$ & $\begin{array}{c}\text { Sig. (2- } \\
\text { tailed) }\end{array}$ & $\begin{array}{c}\text { Mean } \\
\text { Difference }\end{array}$ & $\begin{array}{c}\text { 95\% Confidence } \\
\text { Interval of the } \\
\text { Difference } \\
\text { Lower }\end{array}$ \\
\hline $\begin{array}{l}\text { What do } \\
\text { you think } \\
\text { about } \\
\text { learning } \\
\text { writing }\end{array}$ & 2 & 5 & 4.25 & .776 & 3.189 & 101 & .002 & .245 & .09 & .40 \\
\hline $\begin{array}{l}\text { How do you } \\
\text { evaluate } \\
\text { writing } \\
\text { paragraphs } \\
\text { in English }\end{array}$ & 1 & 5 & 3.34 & .711 & 4.877 & 101 & .000 & .343 & .20 & .48 \\
\hline
\end{tabular}

\subsubsection{Students' evaluation about their writing skills}

Table 2: Students' evaluation about their writing skills

\begin{tabular}{|c|c|c|c|c|c|c|c|c|c|c|}
\hline \multirow[t]{3}{*}{ Ideas } & \multicolumn{4}{|c|}{ Descriptive statistics } & \multicolumn{6}{|c|}{ One-Sample test (test value $=2$ ) } \\
\hline & \multirow[t]{2}{*}{ Min. } & \multirow[t]{2}{*}{ Max } & \multirow[t]{2}{*}{ Mean } & \multirow[t]{2}{*}{$\begin{array}{c}\text { Std. } \\
\text { Deviation }\end{array}$} & \multirow[t]{2}{*}{$\mathbf{t}$} & \multirow[t]{2}{*}{ df } & \multirow[t]{2}{*}{$\begin{array}{l}\text { Sig. (2- } \\
\text { tailed) }\end{array}$} & \multirow[t]{2}{*}{$\begin{array}{c}\text { Mean } \\
\text { Difference }\end{array}$} & \multicolumn{2}{|c|}{$\begin{array}{c}95 \% \text { Confidence } \\
\text { Interval of the } \\
\text { Difference }\end{array}$} \\
\hline & & & & & & & & & Lower & Upper \\
\hline $\begin{array}{l}\text { How do } \\
\text { you } \\
\text { evaluate } \\
\text { your } \\
\text { writing } \\
\text { skill }\end{array}$ & 1 & 4 & 2.71 & .669 & 10.660 & 101 & .000 & .706 & .57 & .84 \\
\hline
\end{tabular}

The table above exhibits that students considered their writing as bad (mean=2.71, $\mathrm{SD}=.669, \mathrm{t}=20.660, \mathrm{df}=101, \mathrm{p}=.000$ ).

\subsubsection{Factors influencing paragraph writing}

Table 3: The influence of vocabulary and grammar

\begin{tabular}{|c|c|c|c|c|c|c|c|c|c|c|}
\hline \multirow[t]{3}{*}{ Ideas } & \multicolumn{4}{|c|}{ Descriptive statistics } & \multicolumn{6}{|c|}{ One-Sample test (test value $=1$ ) } \\
\hline & \multirow[t]{2}{*}{ Min. } & \multirow[t]{2}{*}{ Max } & \multirow[t]{2}{*}{ Mean } & \multirow[t]{2}{*}{$\begin{array}{c}\text { Std. } \\
\text { Deviation }\end{array}$} & \multirow[t]{2}{*}{$\mathbf{t}$} & \multirow[t]{2}{*}{ df } & \multirow[t]{2}{*}{$\begin{array}{l}\text { Sig. (2- } \\
\text { tailed) }\end{array}$} & \multirow[t]{2}{*}{$\begin{array}{c}\text { Mean } \\
\text { Difference }\end{array}$} & \multicolumn{2}{|c|}{$\begin{array}{l}\text { 95\% Confidence } \\
\text { Interval of the } \\
\text { Difference }\end{array}$} \\
\hline & & & & & & & & & Lower & Upper \\
\hline Vocabulary & 4 & 5 & 4.69 & .466 & 14.864 & 101 & .000 & .686 & .59 & .78 \\
\hline Grammar & 4 & 5 & 4.68 & .470 & 14.532 & 101 & .000 & .676 & .58 & .77 \\
\hline
\end{tabular}

Regarding the findings of the table, there is no doubt that numerous students thought vocabulary vastly influenced writing paragraphs (mean=4.69, $\mathrm{SD}=.466, \mathrm{t}=14.864, \mathrm{df}=101$, $\mathrm{p}=.000$ ). In addition, participants agreed that there was a deep influence of grammar on their writing (mean=4.68, $\mathrm{SD}=.470, \mathrm{t}=14.532, \mathrm{df}=101, \mathrm{p}=.000)$. 
Table 4: The influence of idea arrangement and paragraph form

\begin{tabular}{|l|c|c|c|c|c|c|c|c|c|c|}
\hline \multirow{2}{*}{ Ideas } & \multicolumn{3}{|c|}{ Descriptive statistics } & \multicolumn{5}{|c|}{ One-Sample test (test value=1) } \\
\cline { 2 - 10 } & Min. & Max & Mean & $\begin{array}{c}\text { Std. } \\
\text { Deviation }\end{array}$ & $\mathbf{t}$ & $\mathbf{d f}$ & $\begin{array}{c}\text { Sig. (2- } \\
\text { tailed) }\end{array}$ & $\begin{array}{c}\text { Mean } \\
\text { Difference }\end{array}$ & $\begin{array}{c}\text { Interval of the } \\
\text { Difference }\end{array}$ \\
\cline { 3 - 10 } & Lower & Upper \\
\hline $\begin{array}{l}\text { Idea } \\
\text { arrangement }\end{array}$ & 2 & 5 & 4.69 & .526 & 13.173 & 101 & .000 & .686 & .58 & .79 \\
\hline $\begin{array}{l}\text { Paragraph } \\
\text { form }\end{array}$ & 4 & 5 & 4.62 & .488 & 12.773 & 101 & .000 & .618 & .52 & .71 \\
\hline
\end{tabular}

From Table 4, the majority of respondents felt that the arrangement of ideas affected their paragraphs (mean=4.69, $\mathrm{SD}=.526, \mathrm{t}=13.173, \mathrm{df}=101, \mathrm{p}=.000$ ). The form of paragraphs also influenced students' writing (mean=4.62, $\mathrm{SD}=.488, \mathrm{t}=12.773, \mathrm{df}=101, \mathrm{p}=.000)$.

Table 5: The influence of mother tongue and time management

\begin{tabular}{|c|c|c|c|c|c|c|c|c|c|c|}
\hline \multirow[t]{3}{*}{ Ideas } & \multicolumn{4}{|c|}{ Descriptive statistics } & \multicolumn{6}{|c|}{ One-Sample test (test value $=1$ ) } \\
\hline & \multirow[t]{2}{*}{ Min. } & \multirow[t]{2}{*}{$\operatorname{Max}$} & \multirow[t]{2}{*}{ Mean } & \multirow[t]{2}{*}{$\begin{array}{c}\text { Std. } \\
\text { Deviation }\end{array}$} & \multirow[t]{2}{*}{$\mathbf{t}$} & \multirow[t]{2}{*}{ df } & \multirow{2}{*}{$\begin{array}{l}\text { Sig. } \\
(2- \\
\text { tailed })\end{array}$} & \multirow[t]{2}{*}{$\begin{array}{c}\text { Mean } \\
\text { Difference }\end{array}$} & \multicolumn{2}{|c|}{$\begin{array}{l}\text { 95\% Confidence } \\
\text { Interval of the } \\
\text { Difference }\end{array}$} \\
\hline & & & & & & & & & Lower & Upper \\
\hline $\begin{array}{l}\text { Mother tongue } \\
\text { interfere }\end{array}$ & 4 & 5 & 4.62 & .488 & 13.320 & 101 & .000 & .637 & .54 & .73 \\
\hline $\begin{array}{l}\text { Time } \\
\text { management }\end{array}$ & 4 & 5 & 4.64 & .483 & 12.773 & 101 & .000 & .618 & .52 & .71 \\
\hline
\end{tabular}

Table 6: Factors affecting paragraph writing

Reliability Statistics

\begin{tabular}{|c|c|c|}
\hline Reliability Statistics & N of Items \\
\hline Cronbach's Alpha & Cronbach's Alpha Based on Standardized Items & 6 \\
\hline
\end{tabular}

The results from the findings reveal that students concurred with the influence of mother tongue interference (mean=4.62, $\mathrm{SD}=.488, \mathrm{t}=13.320, \mathrm{df}=101, \mathrm{p}=.000$ ). Besides, time management was also a barrier for the majority of participants (mean=4.64, $\mathrm{SD}=.483$, $\mathrm{t}=12.773, \mathrm{df}=101, \mathrm{p}=.000)$. Likewise, the Cronbach's Alpha value $=.611(>.6)$ substantiate that the results were reliable.

\subsubsection{Students' problems in writing paragraphs}

\section{a. Problems with vocabulary}

Table 7: The influence of vocabulary

\begin{tabular}{|l|c|c|c|c|c|c|c|c|c|}
\hline Ideas & \multicolumn{3}{|c|}{ Descriptive statistics } & \multicolumn{5}{|c|}{ One-Sample test (test value=4) } \\
\cline { 2 - 9 } & Min. & Max. & Mean & $\begin{array}{c}\text { Std. } \\
\text { Deviation }\end{array}$ & $\mathbf{t}$ & $\mathbf{d f}$ & $\begin{array}{c}\text { Sig. (2- } \\
\text { tailed) }\end{array}$ & $\begin{array}{c}\text { Mean } \\
\text { Difference }\end{array}$ & $\begin{array}{c}\text { 95\% Confidence } \\
\text { Interval of the } \\
\text { Difference }\end{array}$ \\
\cline { 3 - 9 } \\
$\begin{array}{l}\text { There are so } \\
\text { many words } \\
\text { to remember }\end{array}$
\end{tabular}




\begin{tabular}{|l|c|c|c|c|c|c|c|c|c|c|}
\hline \hline $\begin{array}{l}\text { Students } \\
\text { cannot } \\
\text { express their } \\
\text { ideas } \\
\text { because of } \\
\text { lacking of } \\
\text { vocabulary. }\end{array}$ & 2 & 5 & 4.24 & .663 & 3.586 & 101 & .001 & .235 & .11 & .37 \\
\hline
\end{tabular}

The aftermaths 7 bare that students concurred with the difficulty of vocabulary when writing paragraphs. They strongly agree that there were so many words to remember (mean=4.22, $\mathrm{SD}=.684, \mathrm{t}=3.185, \mathrm{df}=101, \mathrm{p}=.002$ ). This led to the consequence that it was hard for students to express students' ideas because of the lack of vocabulary (mean=4.24, $\mathrm{SD}=.663, \mathrm{t}=3.586, \mathrm{df}=101, \mathrm{p}=.001$ ).

Table 8: Factors of repeating and using suitable word

\begin{tabular}{|c|c|c|c|c|c|c|c|c|c|c|}
\hline \multirow[t]{3}{*}{ Ideas } & \multicolumn{4}{|c|}{ Descriptive statistics } & \multicolumn{6}{|c|}{ One-Sample test (test value=4) } \\
\hline & \multirow[t]{2}{*}{ Min. } & \multirow[t]{2}{*}{ Max. } & \multirow[t]{2}{*}{ Mean } & \multirow[t]{2}{*}{$\begin{array}{c}\text { Std. } \\
\text { Deviation }\end{array}$} & \multirow[t]{2}{*}{$\mathbf{t}$} & \multirow[t]{2}{*}{ df } & \multirow[t]{2}{*}{$\begin{array}{l}\text { Sig. (2- } \\
\text { tailed) }\end{array}$} & \multirow[t]{2}{*}{$\begin{array}{c}\text { Mean } \\
\text { Difference }\end{array}$} & \multicolumn{2}{|c|}{$\begin{array}{c}95 \% \text { Confidence } \\
\text { Interval of the } \\
\text { Difference }\end{array}$} \\
\hline & & & & & & & & & Lower & Upper \\
\hline $\begin{array}{l}\text { Students repeat a } \\
\text { word many times }\end{array}$ & 2 & 5 & 4.31 & .703 & 4.505 & 101 & .000 & .314 & .18 & .45 \\
\hline $\begin{array}{l}\text { Students do not } \\
\text { know which } \\
\text { word is suitable } \\
\text { to use in specific } \\
\text { context. }\end{array}$ & 2 & 5 & 4.47 & .685 & 6.937 & 101 & .000 & .471 & .34 & .61 \\
\hline
\end{tabular}

From the results, it is obvious that students often repeated words in their writing (mean=4.31, $\mathrm{SD}=.703, \mathrm{t}=4.505, \mathrm{df}=101, \mathrm{p}=.000$ ). In addition, the participants felt that utilizing right words in context was really complicated (mean=4.47, $\mathrm{SD}=.685, \mathrm{t}=6.937$, $\mathrm{df}=101, \mathrm{p}=.000)$.

Table 9: Factors of parts of speech, spelling and prepositions

\begin{tabular}{|c|c|c|c|c|c|c|c|c|c|c|}
\hline \multirow[t]{3}{*}{ Ideas } & \multicolumn{4}{|c|}{ Descriptive statistics } & \multicolumn{6}{|c|}{ One-Sample test (test value $=4$ ) } \\
\hline & \multirow[t]{2}{*}{ Min. } & \multirow[t]{2}{*}{ Max. } & \multirow[t]{2}{*}{ Mean } & \multirow[t]{2}{*}{$\begin{array}{c}\text { Std. } \\
\text { Deviation }\end{array}$} & \multirow[t]{2}{*}{$\mathbf{t}$} & \multirow[t]{2}{*}{ df } & \multirow[t]{2}{*}{$\begin{array}{l}\text { Sig. (2- } \\
\text { tailed) }\end{array}$} & \multirow[t]{2}{*}{$\begin{array}{c}\text { Mean } \\
\text { Difference }\end{array}$} & \multicolumn{2}{|c|}{$\begin{array}{c}95 \% \text { Confidence } \\
\text { Interval of the } \\
\text { Difference }\end{array}$} \\
\hline & & & & & & & & & Lower & Upper \\
\hline $\begin{array}{l}\text { I don't know } \\
\text { parts of speech of } \\
\text { words }\end{array}$ & 1 & 5 & 4.25 & .763 & 3.242 & 101 & .002 & .245 & .10 & .40 \\
\hline $\begin{array}{l}\text { I make spelling } \\
\text { mistakes in my } \\
\text { writing } \\
\text { paragraphs }\end{array}$ & 1 & 5 & 4.22 & .816 & 2.669 & 101 & .009 & .216 & .06 & .38 \\
\hline $\begin{array}{l}\text { I also use wrong } \\
\text { prepositions }\end{array}$ & 1 & 5 & 4.25 & .763 & 3.508 & 101 & .001 & .235 & .10 & .37 \\
\hline
\end{tabular}

This result of the table shows that the students encountered problems in using parts of speech in their paragraphs (mean=4.25, $\mathrm{SD}=.763, \mathrm{t}=3.242, \mathrm{df}=101, \mathrm{p}=.002$ ). Moreover, 
problems with spelling in texts were highly permitted (mean $=4.22, \mathrm{SD}=.816, \mathrm{t}=2.669, \mathrm{df}=101$, $\mathrm{p}=.009$ ). Most students agree that they used wrong prepositions (mean=4.25, $\mathrm{SD}=.763$, $\mathrm{t}=3.508, \mathrm{df}=101, \mathrm{p}=.001$ ).

Table 10: Factors of using spoken language and punctuation marks

\begin{tabular}{|c|c|c|c|c|c|c|c|c|c|c|}
\hline \multirow[t]{3}{*}{ Ideas } & \multicolumn{4}{|c|}{ Descriptive statistics } & \multicolumn{6}{|c|}{ One-Sample test (test value $=4$ ) } \\
\hline & \multirow[t]{2}{*}{ Min. } & \multirow[t]{2}{*}{ Max. } & \multirow[t]{2}{*}{ Mean } & \multirow[t]{2}{*}{$\begin{array}{c}\text { Std. } \\
\text { Deviation }\end{array}$} & \multirow[t]{2}{*}{$\mathbf{t}$} & \multirow[t]{2}{*}{ df } & \multirow[t]{2}{*}{$\begin{array}{l}\text { Sig. (2- } \\
\text { tailed) }\end{array}$} & \multirow[t]{2}{*}{$\begin{array}{c}\text { Mean } \\
\text { Difference }\end{array}$} & \multicolumn{2}{|c|}{$\begin{array}{c}95 \% \text { Confidence } \\
\text { Interval of the } \\
\text { Difference }\end{array}$} \\
\hline & & & & & & & & & Lower & Upper \\
\hline $\begin{array}{l}\text { I sometimes use } \\
\text { spoken language } \\
\text { instead of written } \\
\text { one }\end{array}$ & 2 & 5 & 4.34 & .667 & 5.192 & 101 & .000 & .343 & .21 & .47 \\
\hline $\begin{array}{l}\text { I do not know } \\
\text { how to use } \\
\text { punctuation } \\
\text { marks correctly }\end{array}$ & 1 & 5 & 4.35 & .875 & 4.075 & 101 & .000 & .353 & .18 & .52 \\
\hline
\end{tabular}

Table 11: Reliability statistics of vocabulary elements

Reliability Statistics

\begin{tabular}{|c|c|c|}
\hline Cronbach's Alpha & Cronbach's Alpha Based on Standardized Items & N of Items \\
\hline .719 & .719 & 9 \\
\hline
\end{tabular}

According to the findings, students admitted that they used spoken language more often than written one when writing paragraphs (mean=4.34, $\mathrm{SD}=.667, \mathrm{t}=5.192, \mathrm{df}=101, \mathrm{p}=.000$ ). Furthermore, they thought that it was too difficult to utilize punctuation marks perfectly (mean=4.35, $\mathrm{SD}=875, \mathrm{t}=4.075, \mathrm{df}=101, \mathrm{p}=.000$ ). Moreover, the Cronbach's Alpha value $=.719(>.6)$ proves that the results were reliable.

\section{b. Problems with grammar}

Table 12: Factors of various structures and their differences

\begin{tabular}{|c|c|c|c|c|c|c|c|c|c|c|}
\hline \multirow[t]{3}{*}{ Ideas } & \multicolumn{4}{|c|}{ Descriptive statistics } & \multicolumn{6}{|c|}{ One-Sample test (test value $=4$ ) } \\
\hline & \multirow[t]{2}{*}{ Min. } & \multirow[t]{2}{*}{ Max. } & \multirow[t]{2}{*}{ Mean } & \multirow[t]{2}{*}{$\begin{array}{c}\text { Std. } \\
\text { Deviation }\end{array}$} & \multirow[t]{2}{*}{$\mathbf{t}$} & \multirow[t]{2}{*}{ df } & \multirow[t]{2}{*}{$\begin{array}{l}\text { Sig. } \\
(2- \\
\text { tailed) }\end{array}$} & \multirow[t]{2}{*}{$\begin{array}{c}\text { Mean } \\
\text { Difference }\end{array}$} & \multicolumn{2}{|c|}{$\begin{array}{l}\text { 95\% Confidence } \\
\text { Interval of the } \\
\text { Difference }\end{array}$} \\
\hline & & & & & & & & & Lower & Upper \\
\hline $\begin{array}{l}\text { There are so many } \\
\text { structures that I get } \\
\text { confused when } \\
\text { using. }\end{array}$ & 3 & 5 & 4.45 & .591 & 7.709 & 101 & .000 & .451 & .33 & .57 \\
\hline $\begin{array}{l}\text { The differences of } \\
\text { the grammatical } \\
\text { structure between } \\
\text { English and } \\
\text { Vietnamese affect } \\
\text { writing paragraphs. }\end{array}$ & 2 & 5 & 4.29 & .778 & 3.817 & 101 & .000 & .294 & .14 & .45 \\
\hline
\end{tabular}


Regarding grammar, students exceedingly assessed that manifold structures caused perplexity for them (mean=4.45, $\mathrm{SD}=591, \mathrm{t}=7.709, \mathrm{df}=101, \mathrm{p}=.000$ ). Besides, the difference between English and their mother tongue, especially in paragraph writing styles was also consented by English freshmen (mean=4.29, $\mathrm{SD}=.778, \mathrm{t}=3.817, \mathrm{df}=101, \mathrm{p}=.000$ ).

Table 13: Factors of using wrong structures and tenses

\begin{tabular}{|c|c|c|c|c|c|c|c|c|c|c|}
\hline \multirow[t]{3}{*}{ Ideas } & \multicolumn{4}{|c|}{ Descriptive statistics } & \multicolumn{6}{|c|}{ One-Sample test (test value $=4$ ) } \\
\hline & \multirow[t]{2}{*}{ Min. } & \multirow[t]{2}{*}{ Max. } & \multirow[t]{2}{*}{ Mean } & \multirow[t]{2}{*}{$\begin{array}{c}\text { Std. } \\
\text { Deviation }\end{array}$} & \multirow[t]{2}{*}{$\mathbf{t}$} & \multirow[t]{2}{*}{ df } & \multirow[t]{2}{*}{$\begin{array}{l}\text { Sig. (2- } \\
\text { tailed) }\end{array}$} & \multirow[t]{2}{*}{$\begin{array}{c}\text { Mean } \\
\text { Difference }\end{array}$} & \multicolumn{2}{|c|}{$\begin{array}{c}\text { 95\% Confidence } \\
\text { Interval of the } \\
\text { Difference }\end{array}$} \\
\hline & & & & & & & & & Lower & Upper \\
\hline $\begin{array}{l}\text { I usually use } \\
\text { wrong } \\
\text { structures to } \\
\text { express my } \\
\text { meaning }\end{array}$ & 1 & 5 & 4.29 & .778 & 3.817 & 101 & .000 & .294 & .14 & .45 \\
\hline $\begin{array}{l}\text { I utilize wrong } \\
\text { tenses }\end{array}$ & 2 & 5 & 4.31 & .744 & 4.257 & 101 & .000 & .314 & .17 & .46 \\
\hline
\end{tabular}

The outcome presents that English learners consented to use wrong structures when they wanted to express their meaning, leading to misunderstanding or making nonsense sentences (mean=4.29, $\mathrm{SD}=.778, \mathrm{t}=3.817, \mathrm{df}=101, \mathrm{p}=.000$ ). Also, they admitted that they used wrong tenses in their texts (mean=4.31, $\mathrm{SD}=.744, \mathrm{t}=4.257, \mathrm{df}=101, \mathrm{p}=.000$ ).

Table 14: Factors of translating and plural/single of verbs and nouns

\begin{tabular}{|c|c|c|c|c|c|c|c|c|c|c|}
\hline \multirow[t]{3}{*}{ Ideas } & \multicolumn{4}{|c|}{ Descriptive statistics } & \multicolumn{6}{|c|}{ One-Sample test (test value $=4$ ) } \\
\hline & \multirow[t]{2}{*}{ Min. } & \multirow[t]{2}{*}{ Max. } & \multirow[t]{2}{*}{ Mean } & \multirow[t]{2}{*}{$\begin{array}{c}\text { Std. } \\
\text { Deviation }\end{array}$} & \multirow[t]{2}{*}{$\mathbf{t}$} & \multirow[t]{2}{*}{ df } & \multirow[t]{2}{*}{$\begin{array}{l}\text { Sig. (2- } \\
\text { tailed) }\end{array}$} & \multirow[t]{2}{*}{$\begin{array}{c}\text { Mean } \\
\text { Difference }\end{array}$} & \multicolumn{2}{|c|}{$\begin{array}{c}95 \% \text { Confidence } \\
\text { Interval of the } \\
\text { Difference }\end{array}$} \\
\hline & & & & & & & & & Lower & Upper \\
\hline $\begin{array}{l}\text { I am confused of } \\
\text { singular / plural } \\
\text { forms of verbs } \\
\text { and nouns }\end{array}$ & 1 & 5 & 4.36 & .888 & 4.127 & 101 & .000 & .363 & .19 & .54 \\
\hline $\begin{array}{l}\text { I often write } \\
\text { English sentences } \\
\text { by translating } \\
\text { word-by-word } \\
\text { from Vietnamese }\end{array}$ & 1 & 5 & 4.31 & .856 & 3.703 & 101 & .000 & .314 & .15 & .48 \\
\hline
\end{tabular}

Table 15: Reliability statistic of grammar

\begin{tabular}{|c|c|c|}
\hline \multicolumn{2}{|l|}{ Reliability Statistics } & N of Items \\
\hline Cronbach's Alpha & Cronbach's Alpha Based on Standardized Items & 6 \\
\hline .797 & .797 & \\
\hline
\end{tabular}

The results from the table above show that students encountered the confusion of singular and plural forms of verbs and nouns (mean=4.36, $\mathrm{SD}=.888, \mathrm{t}=4.127, \mathrm{df}=101$, $\mathrm{p}=.000$ ). In addition to this, they translated words by words to express their ideas in the paragraphs (mean=4.31, $\mathrm{SD}=.856, \mathrm{t}=3.703, \mathrm{df}=101, \mathrm{p}=.000$ ). Furthermore, the Cronbach's Alpha value $=.797(>.6)$ documents that the results were trustable. 


\section{d. Problems with coherence}

Table 16: Factors of arranging ideas and splitting a paragraph

\begin{tabular}{|c|c|c|c|c|c|c|c|c|c|c|}
\hline \multirow[t]{3}{*}{ Ideas } & \multicolumn{4}{|c|}{ Descriptive statistics } & \multicolumn{6}{|c|}{ One-Sample test (test value $=4$ ) } \\
\hline & \multirow[t]{2}{*}{ Min. } & \multirow[t]{2}{*}{ Max. } & \multirow[t]{2}{*}{ Mean } & \multirow[t]{2}{*}{$\begin{array}{c}\text { Std. } \\
\text { Deviation }\end{array}$} & \multirow[t]{2}{*}{$\mathbf{t}$} & \multirow[t]{2}{*}{ df } & \multirow[t]{2}{*}{$\begin{array}{l}\text { Sig. (2- } \\
\text { tailed) }\end{array}$} & \multirow[t]{2}{*}{$\begin{array}{c}\text { Mean } \\
\text { Difference }\end{array}$} & \multicolumn{2}{|c|}{$\begin{array}{c}95 \% \text { Confidence } \\
\text { Interval of the } \\
\text { Difference }\end{array}$} \\
\hline & & & & & & & & & Lower & Upper \\
\hline $\begin{array}{l}\text { I do not know } \\
\text { how to arrange } \\
\text { the topic } \\
\text { sentence and } \\
\text { supporting ideas. }\end{array}$ & 2 & 5 & 4.38 & .771 & 5.006 & 101 & .000 & .382 & .23 & .53 \\
\hline $\begin{array}{l}\text { I often make } \\
\text { mistakes when } \\
\text { splitting the } \\
\text { paragraphs. }\end{array}$ & 2 & 5 & 4.34 & .862 & 4.022 & 101 & .000 & .343 & .17 & .51 \\
\hline
\end{tabular}

In terms of coherence, there was no doubt that students had problems with arranging the topic and supporting ideas (mean=4.38, $\mathrm{SD}=.771, \mathrm{t}=5.006, \mathrm{df}=101, \mathrm{p}=.000$ ). Moreover, English freshmen assessed that they had problems in splitting paragraphs (mean=4.34, $\mathrm{SD}=.862, \mathrm{t}=4.022, \mathrm{df}=101, \mathrm{p}=.000)$.

Table 17: Factors of making the outline and using linking words

\begin{tabular}{|c|c|c|c|c|c|c|c|c|c|c|}
\hline \multirow[t]{3}{*}{ Ideas } & \multicolumn{4}{|c|}{ Descriptive statistics } & \multicolumn{6}{|c|}{ One-Sample test (test value $=4$ ) } \\
\hline & \multirow[t]{2}{*}{ Min. } & \multirow[t]{2}{*}{ Max. } & \multirow[t]{2}{*}{ Mean } & \multirow[t]{2}{*}{$\begin{array}{c}\text { Std. } \\
\text { Deviation }\end{array}$} & \multirow[t]{2}{*}{$\mathbf{t}$} & \multirow[t]{2}{*}{ df } & \multirow[t]{2}{*}{$\begin{array}{l}\text { Sig. (2- } \\
\text { tailed) }\end{array}$} & \multirow[t]{2}{*}{$\begin{array}{c}\text { Mean } \\
\text { Difference }\end{array}$} & \multicolumn{2}{|c|}{$\begin{array}{c}95 \% \text { Confidence } \\
\text { Interval of the } \\
\text { Difference } \\
\end{array}$} \\
\hline & & & & & & & & & Lower & Upper \\
\hline $\begin{array}{l}\text { I often face } \\
\text { difficulties in } \\
\text { making the } \\
\text { outline for my } \\
\text { writing }\end{array}$ & 2 & 5 & 4.36 & .781 & 4.692 & 101 & .000 & .363 & .21 & .52 \\
\hline $\begin{array}{l}\text { I rarely use } \\
\text { linking words }\end{array}$ & 2 & 5 & 4.27 & .798 & 3.474 & 101 & .001 & .275 & .12 & .43 \\
\hline
\end{tabular}

The results in the table exhibit that students had difficulties in making an outline for a paragraph (mean=4.36, $\mathrm{SD}=.781, \mathrm{t}=4.692, \mathrm{df}=101, \mathrm{p}=.000$ ). Besides, that English freshmen rarely utilized linking words was also found evident (mean=4.27, $\mathrm{SD}=.798, \mathrm{t}=3.474$, $\mathrm{df}=101, \mathrm{p}=.001)$.

Table 18: Factors of types of paragraphs and thinking critically

\begin{tabular}{|c|c|c|c|c|c|c|c|c|c|c|}
\hline \multirow[t]{3}{*}{ Ideas } & \multicolumn{4}{|c|}{ Descriptive statistics } & \multicolumn{6}{|c|}{ One-Sample test (test value $=4$ ) } \\
\hline & \multirow[t]{2}{*}{ Min. } & \multirow[t]{2}{*}{ Max. } & \multirow[t]{2}{*}{ Mean } & \multirow[t]{2}{*}{$\begin{array}{c}\text { Std. } \\
\text { Deviation }\end{array}$} & \multirow[t]{2}{*}{$\mathbf{t}$} & \multirow[t]{2}{*}{ df } & \multirow[t]{2}{*}{$\begin{array}{l}\text { Sig. (2- } \\
\text { tailed) }\end{array}$} & \multirow[t]{2}{*}{$\begin{array}{c}\text { Mean } \\
\text { Difference }\end{array}$} & \multicolumn{2}{|c|}{$\begin{array}{l}95 \% \text { Confidence } \\
\text { Interval of the } \\
\text { Difference }\end{array}$} \\
\hline & & & & & & & & & Lower & Upper \\
\hline $\begin{array}{l}\text { I usually write } \\
\text { wrong types of } \\
\text { paragraphs as }\end{array}$ & 1 & 5 & 4.27 & .903 & 4.400 & 101 & .000 & .373 & .20 & .54 \\
\hline
\end{tabular}




\begin{tabular}{|l|c|c|c|c|c|c|c|c|c|c|}
\hline \hline $\begin{array}{l}\text { required in the } \\
\text { writing tasks }\end{array}$ & & & & & & & & & & \\
\hline $\begin{array}{l}\text { I do not think } \\
\text { critically }\end{array}$ & 1 & 5 & 4.37 & .855 & 3.071 & 101 & .003 & .275 & .10 & .45 \\
\hline
\end{tabular}

Table 19: Reliability statistics of coherence

Reliability Statistics

\begin{tabular}{|c|c|c|}
\hline Cronbach's Alpha & Cronbach's Alpha Based on Standardized Items & N of Items \\
\hline .783 & .783 & 6 \\
\hline
\end{tabular}

From the findings, the majority of students had a setback in recognizing the paragraph types as required in tasks (mean $=4.27, \mathrm{SD}=.903, \mathrm{t}=4.400, \mathrm{df}=101, \mathrm{p}=.000$ ). Furthermore, they admitted that they did not think critically mean=4.37, $\mathrm{SD}=.855, \mathrm{t}=3.071, \mathrm{df}=101$, $\mathrm{p}=.003)$. Furthermore, the Cronbach's Alpha value $=.783(>.6)$ documents that the results were trustworthy.

\subsection{Results of the interview}

Ten students (four boys and six girls) were randomly selected to answer interview questions. In question 1 "Do you like writing? Why or why not?", the majority of students thought that they really liked writing because they could practice the ability of writing and show up their lexicon, and know about the way how to use words. Also, they improved grammar and sentence structures through writing. Moreover, students could recognize their mistakes and problems easily through rechecking their writings. Then they easily fix these problems. However, there were two students who admitted that they did not like writing because they were not good at writing and they did not have a lot of vocabulary and ideas.

In the second question "Do you think writing paragraphs is a difficult skill when learning English? Why or why not?", 100\% of the participants thought that writing paragraphs was very difficult when learning English. Among them, 80\% of the students thought that the reason for the difficulty was the lack of vocabulary and grammar. Furthermore, the arranged topic and supporting ideas were other elements affecting the students.

In the next question "What are problems that you face when writing a paragraph?", Students encountered many problems in writing paragraphs. The majority of students admitted that they did not have enough vocabulary and grammar structures. Besides, students thought that they faced difficult structures of tenses and how to use suitable words in a context. Finally, the minority of them stated that they were not good at idea arrangement, and they sometimes forgot writing topic sentences when writing a paragraph.

As for question 4 "In your opinion, what is the main reason why you cannot write successfully?". In the response to Question 4, eighty percent of the students explained that grammatical structures were the major problem which affected their writings because they translated word by word from the mother tongue to English without correcting 
grammar. In addition, a few students thought that lack of vocabulary was the main reason for their poor writing.

\subsection{Results from the observation}

Thirty participants were asked to write a short paragraph with the topic "Describe a holiday you know". They had 30 minutes to write a paragraph. Then, all papers were collected and marked by an English writing teacher. Basing on the teacher's remarks and correction, problems in students' paragraph writing were identified and presented in the tables below.

Table 20: Lexical problem

\begin{tabular}{|c|l|c|c|}
\hline No & Types of the Problems & Frequency of Occurrences in 30 writings & Percentages (\%) \\
\hline \multicolumn{2}{|l|}{ Problems with vocabulary } & 9 & 30 \\
\hline 1 & Not suitable vocabulary & 2 & 6.7 \\
\hline 2 & Spelling errors & 2 & \\
\hline
\end{tabular}

As seen in Table 20, among 30 paper tests, it can be figured out that in terms of vocabulary problems, students often made mistakes with using inappropriate words (30\%) and rarely made spelling errors in their paragraphs (only 6.7\%).

Table 21: Grammatical problem identified from observation

\begin{tabular}{|c|l|c|c|}
\hline No & Types of the Problems & Frequency of Occurrences in 30 writings & Percentages (\%) \\
\hline \multicolumn{2}{|l|}{ Problems with grammar } & 7 & 23.3 \\
\hline 3 & Parts of speech & 3 & 10 \\
\hline 4 & Grammar structure & 2 & 6.7 \\
\hline 5 & Tenses & 10 & 33.3 \\
\hline 6 & Plural/single forms of nouns & 22 & 73.3 \\
\hline 7 & subject-verb agreement & 24 & 80 \\
\hline 8 & Prepositions & 5 & 16.6 \\
\hline 9 & Articles & 6 & 20 \\
\hline 10 & Punctuations & & \\
\hline
\end{tabular}

Regarding grammatical problems, it can be clearly seen that $80 \%$ of the students of English major faced preposition mistakes. The subject-verb agreement took the second order in the frequency of the mistakes $-73.3 \%$ of the students encountered this type. This showed that prepositions and subject-verb agreement were the English freshmen's serious difficulty in writing paragraphs. Besides, no less important mistake appearing in the writings was plural/single of nouns. One-third of the total number of writing tests made this mistake. It is approximately $33.3 \%$. Nevertheless, only $6.7 \%$ and $10 \%$ of the students used wrong tenses and made structure mistakes, respectively. This indicates that students hardly encountered tenses and grammatical structure mistakes.

As can be seen from Table 22, the researcher found that topic sentence was the major problem students frequently faced. This mistake made up $20 \%$ of the total of writings. Also, it was 13.3 to $16.7 \%$ respectively for mistakes about critical thinking, linking words, concluding sentences occurred in participants' papers. These account for running out of topic, giving irrelevant supporting ideas, and concluding sentences- from 13.3 to $16.7 \%$ made 
these types of mistakes. Nevertheless, it was only two $(6.7 \%)$ in a total of 30 papers that were incomplete ideas. A small minority (3.3\%) out of 30 papers wrote the wrong types of paragraphs.

Table 22: Coherent problem identified from observation

\begin{tabular}{|c|l|c|c|}
\hline No & Types of the Problems & Frequency of Occurrences in 30 writings & Percentages (\%) \\
\hline \multicolumn{2}{|c|}{ Problems with coherence } & 3 & 10 \\
\hline 11 & Ideas arrangement & 1 & 3.3 \\
\hline 12 & Wrong type of paragraphs & 5 & 16.7 \\
\hline 13 & Critical thinking & 4 & 13.3 \\
\hline 14 & Linking words & 6 & 20 \\
\hline 15 & Topic sentences & 4 & 13.3 \\
\hline 16 & Concluding sentences & 5 & 16.7 \\
\hline 17 & Running out of topic & 4 & 13.3 \\
\hline 18 & Irrelevant supporting ideas & 2 & 6.7 \\
\hline 19 & Incomplete ideas & & \\
\hline
\end{tabular}

To sum up, the findings of the observation was completely consistent with the results of the questionnaire. Students encountered grammatical problems more than vocabulary issues. The coherence problem was the least frequent issue that students faced.

\subsection{Discussion}

Thanks to the survey about the students' opinions in learning English and their estimation in paragraph writing, the researcher can evaluate their real thinking about learning English and paragraph writing. It can be said that learning English was extremely important in their thought. Regarding students' evaluation of their own writing skills. The majority of students rated that their writing skills were average or bad, only a few believed their writing skill was good. It is easy to see that they faced some difficulties in writing, especially writing paragraphs. By combining three instruments in this research comprising questionnaire, interview, and observation, it revealed that there were three main causes, i.e. grammar structures, vocabulary, and coherence that prevented students from writing successful paragraphs.

Firstly, the most remarkable result to emerge from the data is that most students faced grammatical problems. This is completely consistent in the questionnaire and observation. Students used prepositions in English wrongly which made it hard to understand. The subject-verb arrangement was difficult which made students' sentences ungrammatical and have wrong meanings. Furthermore, students often did not know clearly the functions and rules of parts of speech so they could misuse the function of the word making it hard for readers to understand the paragraph or their sentences conveyed wrong meaning. Also, using tenses in English wrongly could make readers confused or misunderstand the meaning. However, despite the fact that Dudley Evans \& St John, 1998 found that "some key grammatical forms as tenses, voices, modals, articles, nominalizations, logical connectors", the researcher found that some main grammar structures as subjectverb agreement, prepositions, plural/single of nouns and tenses. 
Secondly, students often lacked the necessary vocabulary when writing. It was a reason why they could not express their thoughts and feelings clearly. They would feel confused when facing unfamiliar topics. Also, choosing appropriate words in contexts was also a difficulty for students since English words often imply different meanings in different contexts. It was one of the difficulties that students often faced. In addition, students used spoken language instead of written one which made the writing less attractive and formal. This confirms previous findings of M.A Hajar (2015) shared in a study that "lacking of vocabulary is one of the sources that make the paragraph less attractive".

Thirdly, coherence was also a problem students faced in writing the paragraphs. They often wrote a paragraph with a wrong or without a topic sentence. Besides, idea arrangement was difficult for students as they often wrote messy arrangement ideas or irrelevant supporting ideas. Our experiments are consistent with the previous results of Husna (2013).

In conclusion, the results of questionnaires, interview, and observation showed that the most common problems of students were mainly on grammar, vocabulary, and coherence. These obstacles blocked students' ability from creating a good paragraph which is very significant to their studying.

\section{Conclusions, Limitations, Implications, and Recommendations}

This chapter includes conclusions, limitations, implications, and recommendations of the research.

\subsection{Conclusions}

English is most widely used in communicating around the world and it is spoken as the mother tongue in many countries. English has become the lingua franca in many fields namely education, business, politics, science, technology, entertainment, etc. Writing in English is important besides speaking because writing not only expresses what a person wants to say or what people think but also saves important information. Hence, this research has highlighted the importance of "EFL student's problems towards paragraph writing at Tay Do university" in order to find out the difficulties students met in paragraph writing and have better writing. However, according to research results, students faced many problems in learning English paragraph writing such as vocabulary, grammar structures, and coherence. The results are expected to let students understand the barriers in their writing, learn from their mistakes, and thus be able to produce better English paragraphs.

\subsection{Limitations}

Despite lots of efforts, limitations are not avoidable in this research. First, it was the time constraint. Because of the COVID-19, both the working schedule of the researcher and the learning plans of the participants changed thoroughly. Thus, since most of the contact was done mainly online, it took more time to collect the data as well as to withdraw the results. Second, because of the change of the schedule, most participants had more tasks 
in their actual class and spent less time on this research. As a result, the research had to arrange many times to meet them to collect enough data which was really frustrating. Apart from these limitations, the researcher hopes that the study can be used as the basis for finding main problems in paragraph writing and hence will be a valuable reference and useful to both teachers and students.

\subsection{Implications}

Regarding students, this research has demonstrated that the freshmen at Tay Do University encountered many problems in writing paragraphs namely vocabulary, grammar, and coherence. This study will also help them recognize their weak points when writing. Therefore, students should innovate their study habits to overcome these problems so that they could gain a better ability of writing paragraphs.

Regarding teachers, this research is also useful for teachers who want to know what difficulties their students often meet. From that, teachers can find teaching methods that are appropriate and more effective to help students develop their writing skills. Also, they can update some new teaching methods and should offer their students suitable materials for learning.

\subsection{Recommendations}

As this research has found out problems students may encounter in their writing, it is suggested that other studies should carry on finding methods to treat these problems so that students will receive the best benefits. Moreover, since the participants of this study were mainly freshmen at university learning writing paragraphs, it is recommended that further research should investigate the problems of writing that other sophomore, junior and senior students may face in their English writing.

\section{Conflicts of interest statement}

The authors whose names are listed immediately below certify that they have no conflicts of interest, authorship, and disclosures in publication. They confirm that this work is original and has not been published elsewhere, nor is it currently under consideration for publication elsewhere.

\section{About the authors}

M.A. Thi Minh Uyen Phan graduated from La Trobe University in Australia and has 20year experience of teaching English; currently is a senior lecturer at Tay Do University. The article co-authors are Thi Thuy Hang Nguyen, Thi Tra My Ly, Thi Thuy Ha Dinh and Thuy Vi Huynh, they are also experienced in teaching English for long time. 


\section{References}

\section{a. References from books}

Ali, A. M. (2016). Investigating The Difficulties Encountered Sudanese University Students in Writing an English Paragraph. Sudan: University of Science and Technology.

Ammar, H. A. J. (2017). Investigating the Difficulties Encounter by EFL Learners in Writing the English Paragraph. Sudan.

Abdel Ghani, S. (2004). An Investigation in Student's Performance in Paragraph Writing at University Level. Gezira.

Brown, H. (2000). Principle of language learning and teaching. London: San Francisco state university.

Byrne, D. (1988). Teaching writing, skills. Hong Kong: Bagman.

Hajar, S. (2015). A Study of Errors in the Paragraph Writing of EFL Learners: A Case Study of First Year Translation Students at University of Applied Science and Technology in Bushehr, Iran. Iran: Bushehr.

Hugo, G. (1999). Advance writing with English in use. Cambridge: Cambridge university press.

Hassan I. A. (2015). Academic writing difficulties of ESI learners.

Lewis, D. (1972). Statistical method in education. London: University of London press

Oshima, A. A, Hogue (2006). Writing Academic English. 4th edition. Pearson Education

Masomeh, A., \& Ali, A. K. (2014). Error Analysis and Paragraph Writing. India.

Martine, L. and Mary, E. (1990). Paragraph develop. American university: Washington D.C.

Muddthir, S. (2007). An investigation problem facing student in writing as a foreign language. UN published MA: Alzaem Alazhari University.

Mumineen, I, M, I. (2012). Problems Encountered in EFL Learners in Paragraph Writing. Sudan.

Ridha, N. (2012). The Effect of EFL Learners' Mother Tongue on their Writings in English. Basrah.

Reddy, K. G. (2006) Paragraph Writing. India: Seasons Publishing.

Simbwa, E. (1987). Investigating Writing Errors among University Students in Uganda. Uganda.

Sawsan, S. A. (2011). Analysis of Errors in Paragraph Writing in English by Second Year Geography E History Students at University of Baghdad. Baghdad.

\section{b. References from the internet}

The First Year Language Students Difficulties in Paragraph Writing and Some Appropriate Strategies to Solve These Problems at The National Economics University (2007). Retrieved from https://123doc.net/document/1028051-the-firstyear-language-students-difficulties-in-paragraph-writing-and-some-appropriatestrategies-to-solve-these-problems-at-the-national-economics-u.htm.

Error Analysis of Written English Paragraphs by Jordanian Undergraduate Students. (2014):

A Case

Study.

Retrieved from 
Thi Tra My Ly, Thi Thuy Hang Nguyen, Thi Minh Uyen Phan, Thi Thuy Ha Dinh, Thuy Vi Huynh EFL STUDENT'S PROBLEMS WITH PARAGRAPH WRITING AT TAY DO UNIVERSITY, VIETNAM

https://www.researchgate.net/publication/281864190 Error Analysis of Written English Paragraphs by Jordanian Undergraduate Students A Case Study. Những con số nói về ngôn ngữ trên thế giới. Vietnamnet. (25/04/2015). Retrieved from https:/vietnamnet.vn/vn/giao-duc/nhung-con-so-noi-ve-ngon-ngu-tren-the-gioi234032.html.

Creative Commons licensing terms

Authors will retain the copyright of their published articles agreeing that a Creative Commons Attribution 4.0 International License (CC BY 4.0) terms will be applied to their work. Under the terms of this license, no permission is required from the author(s) or publisher for members of the community to copy, distribute, transmit or adapt the article content, providing a proper, prominent and unambiguous attribution to the authors in a manner that makes clear that the materials are being reused under permission of a Creative Commons License. Views, opinions, and conclusions expressed in this research article are views, opinions and conclusions of the author(s). Open Access Publishing Group and European Journal of English Language Teaching shall not be responsible or answerable for any loss, damage or liability caused in relation to/arising out of conflict of interests, copyright violations and inappropriate or inaccurate use of any kind content related or integrated on the research work. All the published works are meeting the Open Access Publishing requirements and can be freely accessed, shared, modified, distributed and used in educational, commercial and non-commercial purposes under a Creative Commons Attribution 4.0 International License (CC BY 4.0). 